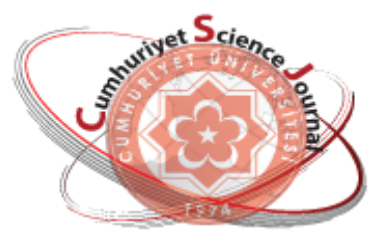

e-ISSN: $2587-246 X$

ISSN: 2587-2680

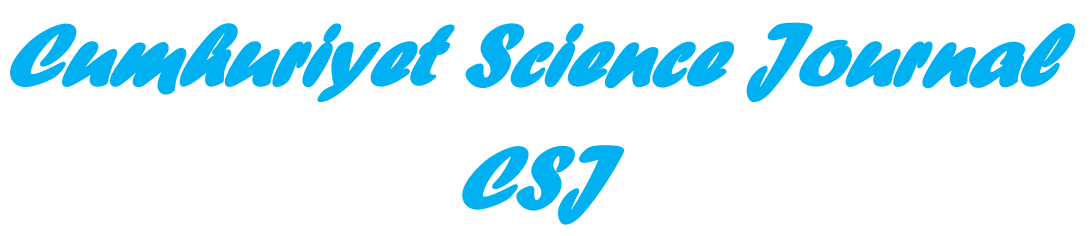

Cumhuriyet Sci. J., Vol.39-2(2018) 413-423

\title{
An Adaptive Neuro-Fuzzy Inference System (ANFIS) of Radioactivity Levels in Hazar Lake
}

\author{
Miraç KAMISLIOGLU ${ }^{1^{*}, \text { Fatih KULAHCI }}{ }^{2}$ \\ ${ }^{1}$ Uskudar University, Vocational School of Health Service, Nuclear Technology and Radiation Safety Department, \\ Istanbul, TURKEY \\ ${ }^{2}$ Firat University, Physics Department, Nuclear Physics Division, Elazig, TURKEY
}

Received: 02.12.2017; Accepted: 01.03.2018

http://dx.doi.org/10.17776/csj.360319

\begin{abstract}
In this study, an Adaptive Neuro-Fuzzy Inference System (ANFIS) model is proposed for the determination of alpha radioactivity of Hazar Lake waters and for the prediction of its unknown values. The model parameters of the lake water are $\mathrm{pH}$, total hardness (TH), depth, electrical conductivity (EC), and alpha radioactivity. ANFIS model is performed using the back-propagation algorithm, which has the five layers. Average relative error between measurements predicted by theoretical (ANFIS) and experimental data is approximately $0.7043 \%$. The relative error between the test data and the radioactivity data change between $0.06 \%$ and $14 \%$. Additionally, validity of the model is also tested with a regression model. The predicted results with the ANFIS model is better as statistically than the regression model.
\end{abstract}

Keywords: ANFIS, Prediction of Radioactivity, Fuzzy Inference System, Hazar Lake.

\section{Hazar Gölü'ndeki Radyoaktif Seviyelerin Belirlenmesi için Uyarlamalı Sinirsel-Bulanık Çıkarım Sistemi (ANFIS) ile Modellenmesi}

\begin{abstract}
Özet. Bu çalışmada, bir Adaptif Sinirsel Bulanık Çıkarım Sistemi (ANFIS) modeli Hazar Gölü (Türkiye) sularının alfa radyoaktivitesinin belirlenmesi ve onun bilinmeyen değerlerinin öngörülmesi için önerilmiştir. Model parametreleri olarak pH, toplam sertlik (TH), derinlik, elektriksel iletkenlik (EC) ve göl suyunun toplam alfa radyoaktivitesi belirlenmiştir. ANFIS modeli beş tabakalı yapı için geri-yayılım algoritması kullanılarak gerçekleştirilmiştir. Teorik ve deneysel (ANFIS) tahmin sonuçları arasındaki ortalama rölatif hata $0.7043 \%$ dir. Test verileriyle radyoaktivite verileri arasındaki rölatif hata $0.06 \%$ ve $14 \%$ arasında değişmiştir. Ek olarak, ANFIS modelinin geçerliliği regresyon modeli ile de test edilmiştir. ANFIS modeli istatistiksel olarak regresyon modelinden daha güvenilir sonuçlar vermiştir.
\end{abstract}

Anahtar Kelimeler: ANFIS, Radyoaktivite Tahmini, Bulanık Çıkarım Sistemi, Hazar Gölü.

\section{INTRODUCTION}

Model is a system to examine the space-time behavior of any physical phenomena through a set of convenient mathematical expressions, which describe linear or non-linear aspects.
Mathematical expressions and modeling of the non-linear systems is comparatively difficult and sometimes requires high speed and memory computers. For this reason, Artificial Neural Networks (ANNs) and Fuzzy Logic (FL) are now commonly used for such modeling [1-7]. 
For instance, the great ecosystems as lakes, have very complex compositions such as Hazar Lake. There are attempts to model such complex structure systems in terms of the physicochemical parameters. Each lake has different parameters within nonlinearly behaviors among themselves. Building a model with classical mathematical methods is quite difficult and may require a series of complex differential equations. In this research, an expert system ANFIS model is proposed for prediction computations. The model input variables are considered as $\mathrm{pH}$, total hardness $(\mathrm{TH})$, electrical conductivity (EC), and depth of water with a single output variable as the total alpha radioactivity of the lake waters. Input parameters are either in directly or indirectly proportional with the exchange of the alpha radioactivity.

Hazar Lake is selected as the study area because its located on East Anatolian Fault Zone (EAFZ). The radioactivity levels along the fault lines are higher than other geological forms [8]. Forecasting studies of radioactivity levels of the Hazar Lake were achieved using an ANNs model by Kulahci et al. [8]. The proposed model in this research has made more accurate predictions for the radioactivity levels in the lake
[8]. According to the best knowledge of the authors, determination of the radioactivity levels with an ANFIS model is not available within the scope of previous studies. Only, Marsequera [11] has studied the modeling with neuro-fuzzy techniques of the water grade in a vapor generator of a pressurized water reactor (PWR). The proposed model can be used also for complex dynamic system such as weather forecast. On the other hand, a regression calculation, in parallel with the ANFIS model, is also suggested, and its results are compared with the ANFIS model.

\section{MATERYAL METHOD}

\subsection{Research Area}

Hazar Lake, located in the east of the Turkey, is a tectonic lake within the EAFZ. The long axis is of about $20 \mathrm{~km}$ in east-southeast and westsouthwest direction. Its altitude is $1248 \mathrm{~m}$ above mean sea level and the surface area is about 81 $\mathrm{km}^{2}$. Geologic structure of the lake base is convenient to absorb and keep the radioactive minerals. The lake is geologically composed of volcanic rocks [8]. The location of the lake and the sampling stations are given as in Fig. 1. Measurement stations are indicated by yellow pin.

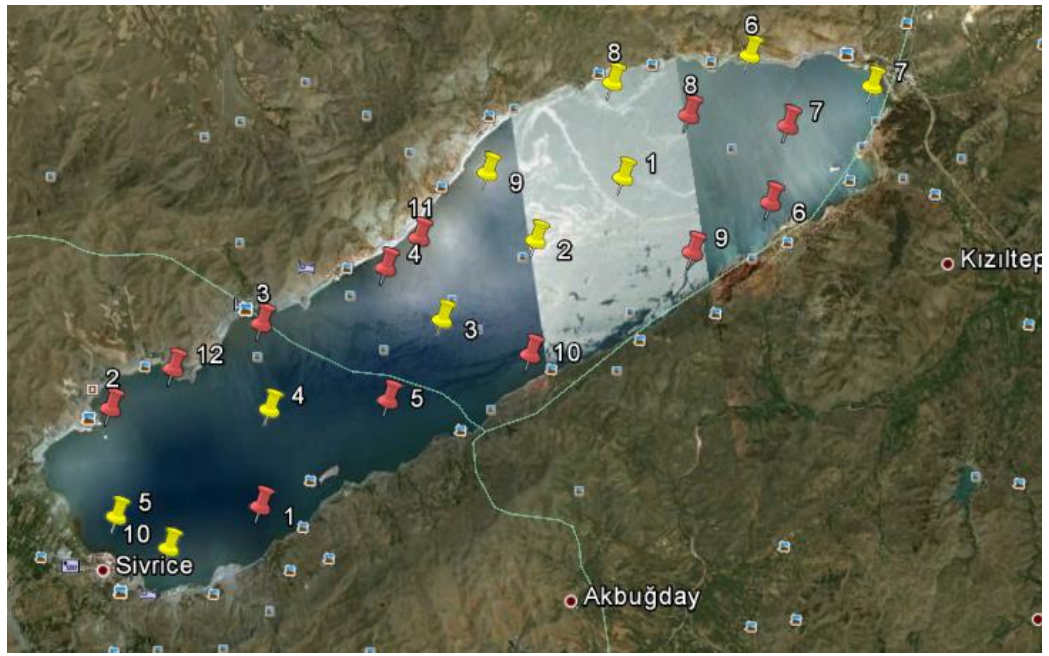

Figure 1. Measurement stations. 


\subsection{Experimental Setup}

\section{Determination of Physicochemical Parameters}

Physicochemical analyses are performed for the forty-five water samples, which are collected from different depths of the lake for 3-year duration (Table 2). The waters are stored in 2liter polyethylene bottles. Prior to storage, bottles are washed with distilled water and 1:1 $\mathrm{HNO}_{3}: \mathrm{H}_{2} \mathrm{O}$. Subsequently, water samples are penetrating Whatman model filter papers and are acidified with ultra-pure $\mathrm{HNO}_{3}(0.2 \mathrm{v} / \mathrm{v})$ in order to reduce the absorption of the elements onto the bottle wall and are stocked approximately at 4-5 ${ }^{\circ} \mathrm{C}$. $\mathrm{TH}, \mathrm{pH}, \mathrm{EC}, \mathrm{pH}$ measurements of the water samples is determined as chemical which are performed with an Orion 230A digital $\mathrm{pH}$ meter. Electrical conductivity (EC) measurements have been obtained with Jenway 4070 digital conduct meter. Total hardness of water is determined with the titrimetric method [12]. The $\mathrm{pH}$ and the EC measurements of waters are achieved in the research basin.

\section{Radioactivity Analysis}

The waters samples in 2-liter polyethylene bottles, which are acidified with $\mathrm{HNO}_{3}$ are transferred into three equal volume containers $(100 \mathrm{ml})$. Waters in the containers are evaporated at approximately $50{ }^{\circ} \mathrm{C}$. After evaporation, residues in the container are poured into another vessel of roughly $4.5 \mathrm{~cm}^{3}$. Al planchettes and dried under the UV lamb (456 $\mathrm{nm})$. Precipitations in the planchettes are directly counted in the counting system. Three counts are obtained for each sample, and thus, the statistical reliability is improved. Then, the arithmetic means of the counts are computed and the radioactivity levels are determined.

The radioactivity measurements are achieved by the Krieger method [13] using an alpha spectroscopy system. The system consists of a $\mathrm{ZnS}(\mathrm{Ag})$ scintillator, a photomultiplier tube, and a7286 low-level alpha counter (NE Technology). The $\mathrm{ZnS}(\mathrm{Ag})$ scintillator has a radius of $44 \mathrm{~mm}$. The total alpha radioactivity calculation is made according to the following equation:

$$
A_{\alpha}=(N \cdot E C F) / 2.22
$$

where $\mathrm{A}_{\alpha}$ is the alpha activity in $\mathrm{pCi} ; \mathrm{N}$ is the net count in a minute; and ECF is the correction factor. ECF is determined from the thickness of the residue on the planchette as follows:

$E C F=1 / E \cdot T$

where $\mathrm{T}$ is obtained from the $\mathrm{U}_{3} \mathrm{O}_{8}$ selfabsorption curves in $\mathrm{mg} / \mathrm{cm}^{2}$, where $\mathrm{E}$ is the absolute efficiency.

\subsection{Theoretical}

Adaptive Network Based on Fuzzy Inference System (ANFIS)

The ANFIS methodology was improved by Jang [14] and has been used for the modeling of the non-linear functions and the estimation of the chaotic time series. The fuzzy if-then rules reflect human thought and knowledge of the learning capabilities of the ANNs. ANNs in ANFIS are used to determine the parameters of the fuzzy system, which after the learning phase works without any need to ANNs. ANFIS uses ANNs for training of the system and decisionmaking process.

Advantages of ANFIS

(a) ANFIS capable of both learning and linguistic expression.

(b) It processes numerical, logical or linguistic data. 
(c) Solving of the non-linear problems can be examined with the fuzzy logic.

(d) Membership functions (MFs) of fuzzy system can easily be estimated with the help of ANNs.

ANFIS bases on Takagi-Sugeno fuzzy model [15], which is also referred to as the TakagiSugeno neuro-fuzzy system learning algorithm that is formed by unite of the least squares method and the back-propagation learning algorithm through a hybrid learning algorithm. The learning involves two steps: The first produces the input values into the system and the appropriate outcome parameters are acceptable by the least squares method. On the second step, these parameters take the place of previous parameters. Numbers of iterations increase within the recommended limits until they can reach the appropriate parameter values. ANFIS model training can be completed at the end of iteration. After this step, the model can control the problem [16]. ANFIS is an off-line learning model and it is completely used in modeling and control of dynamic systems by making a set of fuzzy if-then rules with suitable MFs [17,18]. Unlike our previous study of complex dynamic system "Chaotic Behavior of Soil Radon Gas and Applications", in this research we used ANFIS model which consist of five layers (Fig. 2) [19].

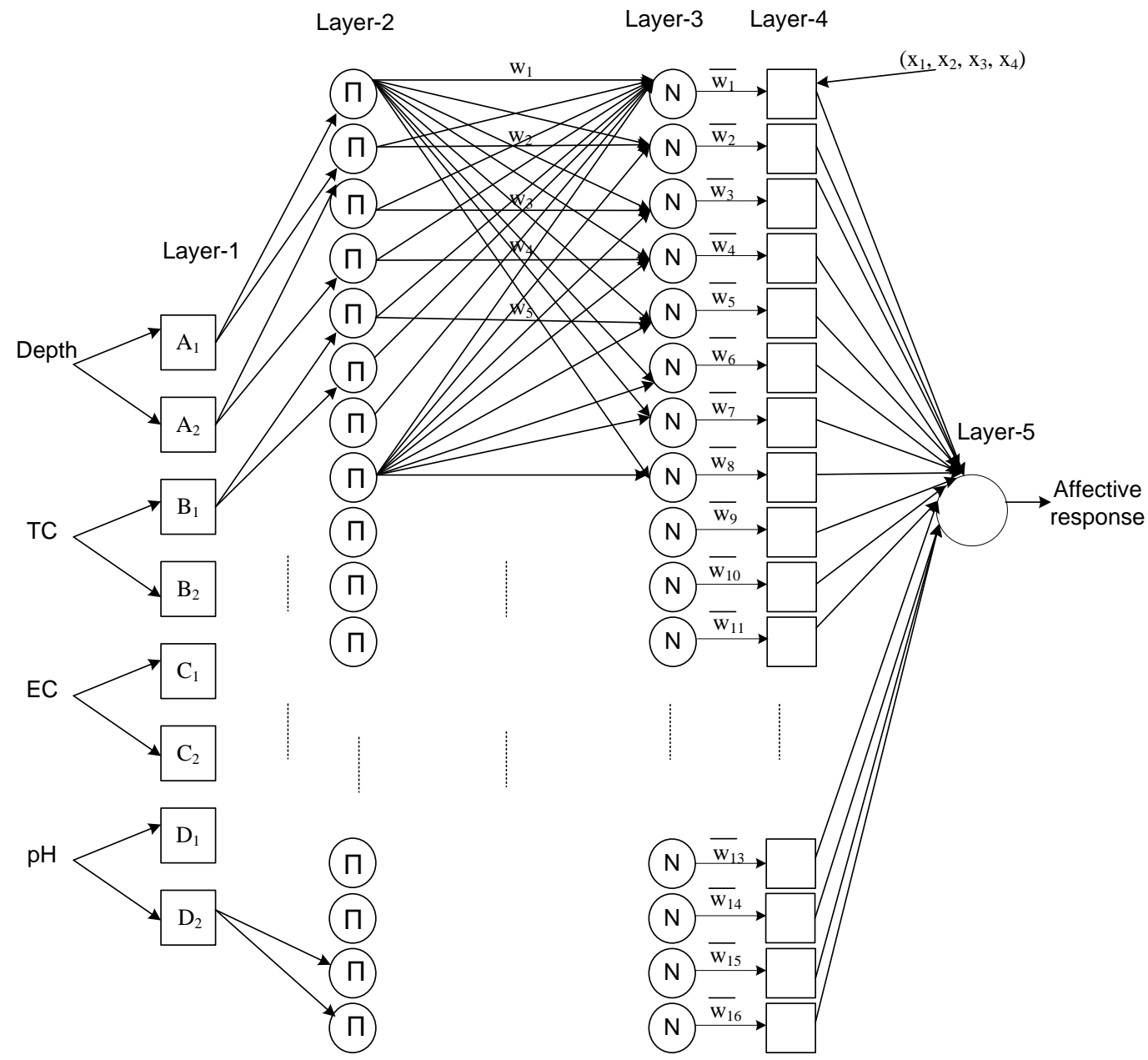

Figure 2. ANFIS architecture. 
Water depth, total hardness, electrical conductivity, and $\mathrm{pH}$ was used as input parameters and

total alpha radioactivity was defined as output parameter for the creation of the ANFIS architecture. If-then rules, which have been used in the model architecture, can be written as follows:

If $x_{1} A_{1} x_{2} B_{2} x_{3} C_{3} x_{4} D_{4}$

then $f_{1}=p x_{1}+q x_{2}+r x_{3}+s x_{4}+m$,

where $\mathrm{p}, \mathrm{q}, \mathrm{r}, \mathrm{s}$, and $\mathrm{m}$ are the linear output parameters. Architecture of the proposed model has five layers and sixteen if-then rules.
Table 1. Architecture and training parameters of the proposed ANFIS.

\begin{tabular}{ll}
\hline Architecture & \\
\hline Number of layers & 5 \\
\hline Number of parameter & Input:4, Output:1, Rules:16 \\
\hline Input membership functions & Bell-shaped \\
\hline Activation functions & Log-sigmoid \\
\hline Training parameters & Hybrid learning algorithm \\
\hline Learning rule & Back-propagation \\
\hline Reaching epochs & 105 \\
\hline
\end{tabular}

The properties of ANFIS architecture that will created is given in Table 1 .

\section{RESULTS and DISCUSSION}

The arithmetic mean values of chemical and physical measurements for the same stations along 3 years are indicate in Table 2. $20 \%$ of forty-five data are selected as test data, while the remaining values are selected as training data (Table 1). 
Table 2. Arithmetic means of chemical and physical parameters in Hazar Lake.

\begin{tabular}{|c|c|c|c|c|c|}
\hline $\begin{array}{c}\text { Station } \\
\text { Number }\end{array}$ & Depth (m) & $\begin{array}{c}\mathrm{TH} \\
\left(\mathrm{mgCaCO}_{3} / \mathrm{l}\right)\end{array}$ & $\begin{array}{c}\text { EC } \\
(\mu \mathrm{mho} / \mathrm{cm})\end{array}$ & pH & $\begin{array}{c}\text { Alpha } \\
\text { radioactivity- } \\
\text { Experimental- } \\
(\mathrm{Bq} / \mathrm{l})\end{array}$ \\
\hline 1 & 0.15 & 375 & 19.2 & 7.13 & 0.12 \\
\hline 2 & 0.15 & 375 & 21 & 8 & 0.2 \\
\hline 3 & 0.15 & 380 & 21 & 8.04 & 0.24 \\
\hline 4 & 0.15 & 400 & 21 & 8.12 & 0.26 \\
\hline 5 & 0.15 & 420 & 21.2 & 8.14 & 0.26 \\
\hline $6^{\mathrm{a}}$ & 0.15 & 420 & 21.7 & 8.15 & 0.31 \\
\hline 7 & 0.15 & 430 & 22 & 8.17 & 0.315 \\
\hline 8 & 0.15 & 430 & 22 & 8.18 & 0.33 \\
\hline 9 & 0.15 & 430 & 22 & 8.18 & 0.42 \\
\hline $10^{\mathrm{a}}$ & 0.15 & 432 & 22.4 & 8.22 & 0.43 \\
\hline 11 & 0.15 & 433 & 22.4 & 8.23 & 0.45 \\
\hline 12 & 0.15 & 433 & 22.4 & 8.26 & 0.51 \\
\hline 13 & 0.15 & 435 & 22.5 & 8.26 & 0.56 \\
\hline $14^{\mathrm{a}}$ & 0.15 & 440 & 22.6 & 8.27 & 0.574 \\
\hline 15 & 0.15 & 440 & 22.6 & 8.28 & 0.61 \\
\hline 16 & 0.15 & 460 & 22.6 & 8.28 & 0.637 \\
\hline 17 & 0.15 & 462 & 22.8 & 8.3 & 0.64 \\
\hline $18^{\mathrm{a}}$ & 0.15 & 465 & 22.9 & 8.3 & 0.651 \\
\hline 19 & 0.15 & 465 & 23 & 8.3 & 0.66 \\
\hline 20 & 0.15 & 468 & 23 & 8.32 & 0.71 \\
\hline 21 & 0.15 & 470 & 23 & 8.33 & 0.71 \\
\hline $22^{\mathrm{a}}$ & 0.15 & 470 & 23 & 8.33 & 0.72 \\
\hline 23 & 3 & 474 & 23 & 8.33 & 0.76 \\
\hline 24 & 4 & 476 & 23 & 8.35 & 0.775 \\
\hline 25 & 4 & 478 & 23 & 8.36 & 0.8 \\
\hline $26^{\mathrm{a}}$ & 5 & 480 & 23.1 & 8.37 & 0.828 \\
\hline 27 & 5 & 480 & 23.1 & 8.38 & 0.83 \\
\hline 28 & 5 & 480 & 23.1 & 8.38 & 0.833 \\
\hline 29 & 5.5 & 480 & 23.2 & 8.38 & 0.87 \\
\hline $30^{\mathrm{a}}$ & 6 & 480 & 23.2 & 8.38 & 0.88 \\
\hline 31 & 8 & 480 & 23.2 & 8.38 & 0.913 \\
\hline 32 & 8 & 482 & 23.2 & 8.4 & 0.93 \\
\hline 33 & 11 & 490 & 23.2 & 8.4 & 0.933 \\
\hline $34^{\mathrm{a}}$ & 12 & 490 & 23.3 & 8.41 & 0.933 \\
\hline 35 & 15 & 490 & 23.3 & 8.42 & 0.957 \\
\hline 36 & 24 & 493 & 23.4 & 8.44 & 0.96 \\
\hline 37 & 25 & 505 & 23.4 & 8.48 & 0.97 \\
\hline $38^{\mathrm{a}}$ & 25 & 505 & 23.5 & 8.48 & 1.07 \\
\hline 39 & 25 & 515 & 23.5 & 8.5 & 1.12 \\
\hline 40 & 30 & 515 & 23.6 & 8.5 & 1.145 \\
\hline 41 & 32 & 517 & 23.7 & 8.5 & 1.19 \\
\hline 42 & 45 & 520 & 23.8 & 8.5 & 1.22 \\
\hline 43 & 60 & 520 & 24.2 & 8.59 & 1.25 \\
\hline 44 & 64 & 525 & 24.4 & 8.64 & 2.51 \\
\hline 45 & 90 & 525 & 27.7 & 9.65 & 2.7 \\
\hline
\end{tabular}

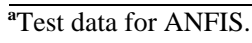


The reaction term that is an expression of degree of alcalinity of water or alcalinity is used to indicate neutral, acidic or alkaline of a medium. Briefly, it is shown with the $\mathrm{pH}$ symbol. $\mathrm{pH}$ of a medium indicates the density of hydrogen ions in the environment. It is seen that $\mathrm{pH}$ values of the lake water change between 7.13 and 9.65 in Table 2.

The most important factor affecting alkalinity of water is carbonate and the bicarbonate salts. On the other hand, the electric current passing of the water depends on the concentration and type of ions in the water. The greater the ion density the higher the water permeability and the lesser the resistance [8].

The electrical conductivity (EC) of the Hazar Lake varies between 19.2-27.7 $\mu \mathrm{mho} / \mathrm{cm}$ (Table $2)$. The EC values of the surface water are closes to each other in general. It is seen that the EC depends on the decrease of the gross alpha radioactivity. The reason for this is ions such as hydrogen that acts on the alpha radioactivity and increases the EC.

The total hardness (TH) of water occurs from melting of minerals in the soil that has been in contact with the water. $\mathrm{Ca}$ and $\mathrm{Mg}$ elements form the hardness of water. They have the low melting ability in the pure water. If water includes $\mathrm{CO}_{2}$, then the carbonic acid occurs. The carbonic acid melts the limestone and turns into bicarbonate. Thus, $\mathrm{CO}_{2}$ is seen as the most important factor forming the hardness of water [8]. The $\mathrm{TH}$ of water samples taken from the Hazar Lake varies between 375-520 mgCaCO3/1 (Table 2). The statistical variations of data are given in Table 3.

Table 3. The basic statistical analysis for the alpha radioactivity.

\begin{tabular}{lll}
\hline Radioactivity & Measured values & Predicted values \\
\hline Sampling Number & 45 & 45 \\
Minimum radioactivity & 0.12 & 0.119 \\
Maximum radioactivity & 2.7 & 2.7 \\
Mean & 0.7932 & 0.7907 \\
Median & 0.76 & 0.7586 \\
Standart error & 0.07344 & 0.07343 \\
Standart deviation & 0.4927 & 0.4926 \\
\hline
\end{tabular}

The inputs using in this research are selected from parameters which directly affect the model output. They are depth, TH, EC, and $\mathrm{pH}$ of Hazar Lake, respectively. The output is alpha radioactivity. $20 \%$ of the forty-five data was selected as test data and the remaining $80 \%$ of data was chosen as the training data. Comparison of measured (experimental) and theoretical (predicted) results is shown in the Fig. 3. It is showed that the relative error between these results is among $0 \%$ and $14 \%$ (Table 5). The maximum acceptable error at the practical applications is about $15 \%$. On the other hand, changing between the test data and the proposed model is given in Fig. 4. 


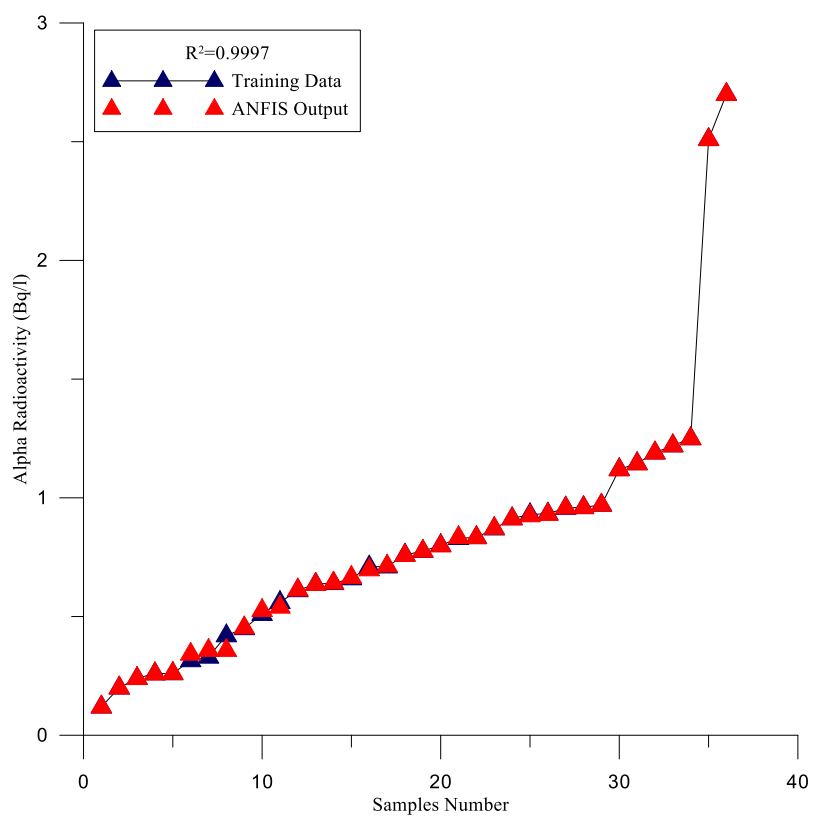

Figure 3. Changing between training data and ANFIS output.

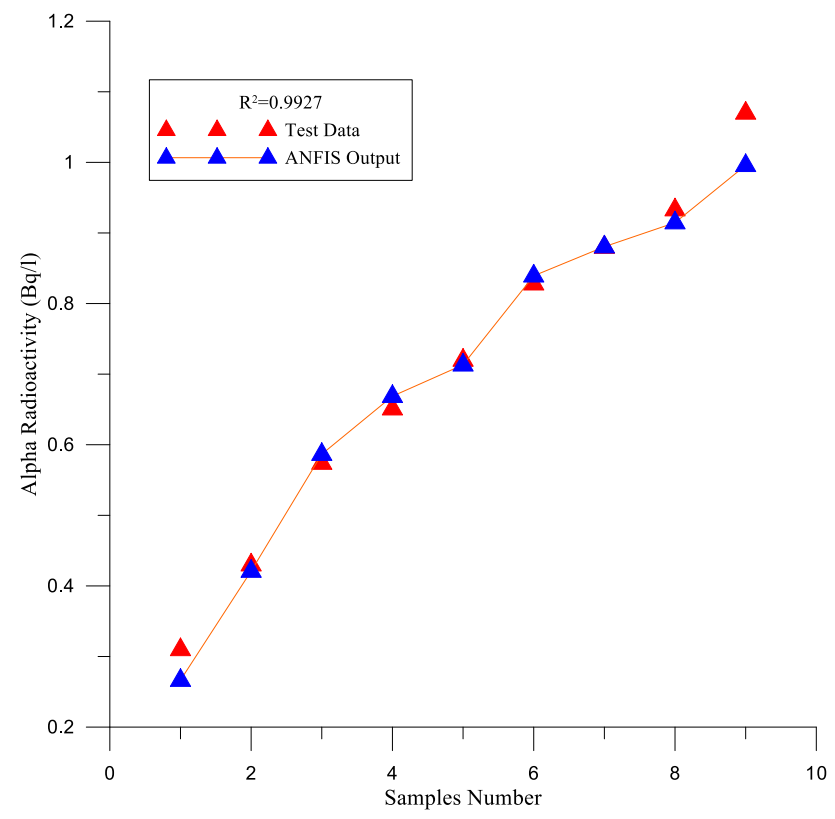

Figure 4. Changing between test data and ANFIS output.
A regression model to compare with outputs of ANFIS is obtained from the Hazar Lake data. The regression equation is as follows:

Alpha Radioactivity $=1.28 \cdot 10^{-2} \times$ Depth + $2.755 \cdot 10^{-4} \times \mathbf{T C}+0.315 \times \mathbf{E C}-0.488 \times \mathbf{p H}-$ 2.599 (11)

Comparison of the regression model and the ANFIS model is given in Table 5. As shown in the Table 5, the ANFIS model has given more consistent results than the regression model. 
Table 5. Comparison of theoretical (predicted) radioactivity and experimental radioactivity for test data.

\begin{tabular}{|c|c|c|c|c|c|c|c|c|c|}
\hline $\begin{array}{l}\text { Station } \\
\text { Number }\end{array}$ & $\begin{array}{l}\text { Depth } \\
\text { (m) }\end{array}$ & $\begin{array}{c}\mathrm{TH} \\
\left(\mathrm{mgCaCO}_{3} / \mathrm{l}\right)\end{array}$ & $\begin{array}{c}\mathrm{EC} \\
(\mu \mathrm{mho} / \mathrm{cm})\end{array}$ & $\mathrm{pH}$ & $\begin{array}{c}\text { Experimental } \\
(\mathrm{Bq} / \mathrm{l})\end{array}$ & $\begin{array}{l}\text { Predicted } \\
\text { ANFIS } \\
(\mathrm{Bq} / \mathrm{l})\end{array}$ & $\begin{array}{l}\text { Relative } \\
\text { Error }^{\mathrm{a}}\end{array}$ & $\begin{array}{l}\text { Predicted } \\
\text { Regression } \\
(\mathrm{Bq} / \mathrm{l})\end{array}$ & $\begin{array}{l}\text { Relative } \\
\text { Error }^{\mathrm{a}}\end{array}$ \\
\hline 6 & 0.15 & 420 & 21.7 & 8.15 & 0.31 & 0.2665 & $14 \%$ & 0.376 & $21.20 \%$ \\
\hline 10 & 0.15 & 432 & 22.4 & 8.22 & 0.43 & 0.421 & $0.90 \%$ & 0.566 & $31.60 \%$ \\
\hline 14 & 0.15 & 440 & 22.6 & 8.27 & 0.574 & 0.5866 & $2.19 \%$ & 0.607 & $5.74 \%$ \\
\hline 18 & 0.15 & 465 & 22.9 & 8.3 & 0.651 & 0.6687 & $2.71 \%$ & 0.694 & $6.60 \%$ \\
\hline 22 & 0.15 & 470 & 23 & 8.33 & 0.72 & 0.7132 & $0.94 \%$ & 0.729 & $1.25 \%$ \\
\hline 26 & 5 & 480 & 23.1 & 8.37 & 0.828 & 0.8393 & $1.36 \%$ & 0.789 & $4.71 \%$ \\
\hline 30 & 6 & 480 & 23.2 & 8.38 & 0.88 & 0.8805 & $0.06 \%$ & 0.828 & $5.99 \%$ \\
\hline 34 & 12 & 490 & 23.3 & 8.41 & 0.933 & 0.9146 & $1.97 \%$ & 0.89 & $4.60 \%$ \\
\hline 38 & 25 & 505 & 23.5 & 8.48 & 1.07 & 0.9958 & $7 \%$ & 1.124 & $5.04 \%$ \\
\hline
\end{tabular}

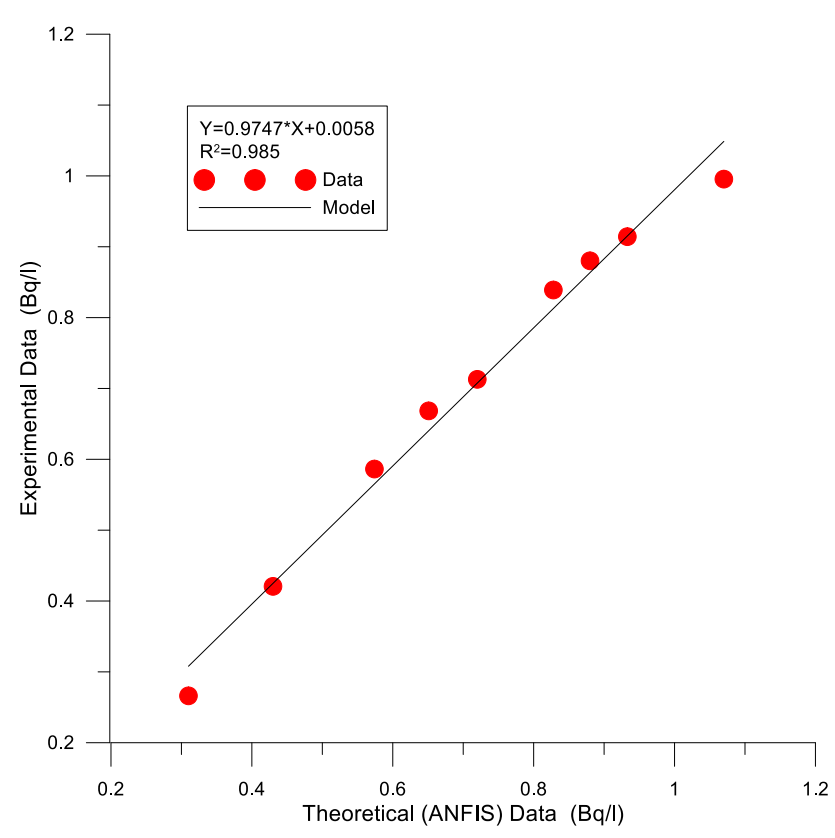

Figure 6. Scatter diagram for the experimental data and the theoretical data.

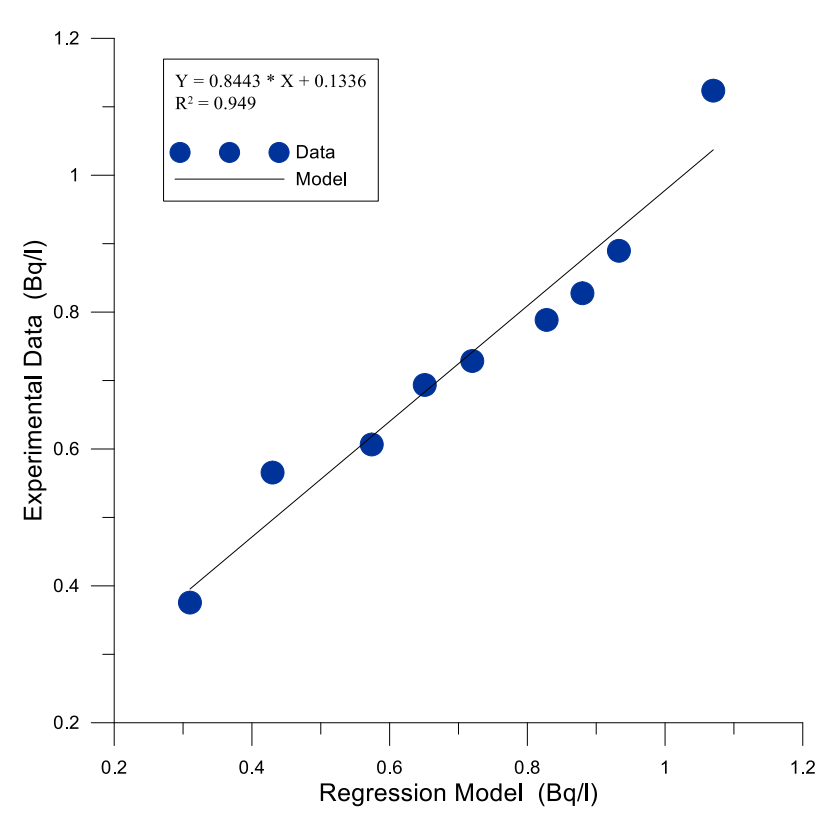

Figure 7. Scatter diagram for the experimental data and regression model. 


\section{CONCLUSIONS}

In this work, the alpha radioactivity concentrations of Hazar Lake are predicted using the ANFIS model. This model can be easily controlled the amounts of the physico-chemical parameters. Removing and controlling of radioactive contaminations in waters and/or any other systems are quite difficult, expensive, and time-consuming. The proposed model is the easier and takes less time than the classical methods.

It is showed that the ANFIS model is compatible with the experimental results. The model, which has the learning ability and the parallel computation of ANN and FL, is a hybrid artificial intelligence method. It has the advantages of both ANN and FL methods and gives an opportunity for solution of critic and the complex problems. In addition, it can also be used in other areas. The other important topics in this work can be listed as follows:

(i) The surface waters and the shallow waters include the high uranium concentrations. Therefore, the total alpha radioactivity has high concentrations in the lake.

(ii) There is a linear relationship between total radioactivity and hardness.

(iii) In comparison of experimental and corresponding prediction data, it has been clearly observed that the results from ANFIS prediction obtain with a fairly low error as $0.7043 \%$.

(iv) Nonlinear structure can well be modeled with the ANFIS architecture.

(v) Under normal circumstances, such as in this study, it is very difficult to model a system with pure-differential equations. In fact, it may even be impossible if the model has many parameters as in this research. However, the proposed ANFIS model does not require complex mathematical operations.

\section{REFERENCES}

[1]. Dragovic S. and Antonije O., Classification of soil samples according to geographic origin using gamma-ray spectrometry and pattern recognition methods. Appl Radiat. Isotopes., 65 (2007) 218-224.

[2]. Baylar A. Hanbay D. and Batan M., Application of least square support vector machines in the prediction of aeration performance of plunging overfall jets from weirs, Expert Syst. Appl., 36 (2009) 83688374.

[3]. Külahcı F. İnceöz M. Doğru M. Aksoy E. and Baykara O., Artificial neural network model for earthquake prediction with radon monitoring. Appl Radiat. Isotopes., 67 (2009) 212-219.

[4]. Gueldal V. and Tongal H., Comparison of recurrent neural network, adaptive neurofuzzy inference system and stochastic models in Egirdir Lake level forecasting. Water Resour Manag, 24 (2010) 105-128.

[5]. Talebizadeh M. and Moridnejad A., Uncertainty analysis for the forecast of lake level fluctuations using ensembles of ANN and ANFIS models, Expert Syst. Appl., 38 (2011) 4126-4135.

[6]. Abed-Erndoust A. and Kerachian R., Wave height prediction using the rough set theory. Ocean Eng., 54 (2012) 244-250.

[7]. Kisi O. Shiri J. and Nikoofar B., Forecasting daily lake levels using artificial intelligence approaches, Comput Geosci., 41 (2012) 169-180.

[8]. Kulahci F. Özer AB. and Doğru M., Prediction of the radioactivity in Hazar Lake (Sivrice, Turkey) by artificial neural networks, J Radioanal Nucl Ch., 269 (2006) 63-68.

[9]. Kulahci F. and Dogru M., The physical and chemical researches in water and sediment of Keban Dam Lake, Turkiye: part 1- 
radioactivity iso-curves., J Radioanal Nucl Ch., 268 (2006) 517-528.

[10].Kulahci F. and Doğru M., Physical and chemical investigation of water and sediment of the Keban Dam Lake, Turkey: Part 2: Distribution of radioactivity, heavy metals and major elements, J. Radioanal. Nucl. Ch., 268 (2006b) 529-537.

[11].Marsequera M., Model identification by neuro-fuzzy techniques: predicting the water level in a steam generator of a PWR, Prog Nucl Energ., 44 (2004) 237-252.

[12].Tokalioglu S. and Kartal S., Chemometrical interpretation of lake waters after their chemical analysis by using AAS flame photometry and titrimetric techniques, Int J Environ An Ch., 82 (2002) 291-305.

[13].Krieger LH., Interim radiochemical methodology from drinking water., EPA 600(4), 75-008, Cincinnati, Ohio,1975 pp 20-100.
[14].Jang JSR., ANFIS: Adaptive-network-based fuzzy inference system, IEEE T Syst Man Cy., 23 (1993) 665-685.

[15].Takagi T., and Sugeno M., Fuzzy identification of systems and its applications to modeling and control. IEEE T Syst Man Cy., 15 (1985) 116-132.

[16].Takagi H, and Hayashi I., NN-driven fuzzy reasoning., Int J Approx Reason., 5 (1991) 91-212.

[17].Melin P. and Castillo O., Intelligent control of a steepping motor drive using an adaptive neuro- fuzzy inference system, Inform Sciences., 170 (2005) 133-151.

[18].Mon YJ., Airbag controller designed by adaptive- network-based fuzzy inference system (ANFIS), Fuzzy Sets Syst., 158 (2007) 2706-2714.

[19].Kamışlığlu M. and Külahcı F., Chaotic Behavior of Soil Radon Gas and Applications, Acta Geophysica., 64(5) (2016) 1563-1592. 